\title{
Transmission and Propagation of 'Candidatus Liberibacter asiaticus' by Grafting with Individual Citrus Leaves
}

\author{
Mark E. Hilf and Reid S. Lewis
}

United States Department of Agriculture-Agricultural Research Service, 2001 S. Rock Road, Fort Pierce, FL. Accepted for publication 11 January 2016.

\begin{abstract}
Hilf, M. E., and Lewis, R. S. 2016. Transmission and propagation of 'Candidatus Liberibacter asiaticus' by grafting with individual citrus leaves. Phytopathology 106:452-458.

Huanglongbing (HLB) is a chronic, progressive decline disease in citrus associated with a systemic infection by the bacterium 'Candidatus Liberibacter asiaticus'. Transmission of the bacterium in the field is by the Asian citrus psyllid, Diaphorina citri Kuwayama. Experimental propagation of ' $\mathrm{Ca}$. L. asiaticus' is done primarily by grafting pieces of bud wood from an infected plant. To produce a small-scale model system for investigation of pathogen biology, we investigated grafting single leaves from infected citrus plants as sources of inoculum for propagation of the bacterium. In total, 162 plants ranging in age from 3 to 18 months

were grafted. Grafting with intact asymptomatic and HLB-symptomatic leaves resulted in 61 of $78(78 \%)$ and 35 of $41(85 \%)$ of the plants infected with ' $\mathrm{Ca}$. L. asiaticus', respectively. Inoculum consisting of the leaf petiole only or only an inoculum tissue remnant under the bark of the receptor tree resulted in 6 of $12(50 \%)$ and 7 of 31 (23\%) infected trees, respectively. Real-time polymerase chain reaction (qPCR) assays verified the infection in plants, a majority of which developed the foliar blotchy mottle symptom considered diagnostic for HLB, while some plants also displayed the stunted, chlorotic shoots for which the disease is named. The qPCR data together with the symptoms displayed demonstrated that individual leaves from infected trees can serve as effective inoculum sources for transmission and propagation of ' $C a$. L. asiaticus' via grafting.
\end{abstract}

Huanglongbing (HLB), also known as citrus greening, is a progressive, systemic, bacterial decline disease of citrus. In most major citrus-growing areas where the disease is present, including China, India, the United States, and Mexico, the disease is associated with a systemic infection by the $\alpha$-proteobacterium 'Candidatus Liberibacter asiaticus' (Bové 2006; Gottwald et al. 2007) whereas, in Brazil, it is associated with infection primarily by ' $\mathrm{Ca}$. L. asiaticus' (Coletta-Filho et al. 2004) but also with ' $\mathrm{Ca}$. L. americanus' (Lopes et al. 2009b; Teixeira et al. 2005) and, in South Africa, the associated pathogen is ' $C a$. L. africanus' (Pietersen et al. 2010). Infected trees may show a variety of symptoms, including chlorosis and dieback of shoots, but a foliar symptom described as blotchy mottle is considered the characteristic symptom of HLB in many citrus varieties. In addition, fruit may show various symptoms, including being undersized, deformed, and poorly colored (Bové 2006; Gottwald et al. 2007).

Transmission of ' $\mathrm{Ca}$. L. asiaticus' in the field is by the Asian citrus psyllid (ACP), Diaphorina citri Kuwayama (Bové 2006; Gottwald et al. 2007). In the continental United States, the ACP vector was first identified in Florida in 1998 (Halbert 1998) and subsequently in Texas in 2001 (French et al. 2001) and California in 2008 (https://www.cdfa.ca.gov/egov/Press_Releases/Press_Release. asp?PRnum=08-057). The ACP is now well established in all three states, which are the three largest commercial producers of citrus in the United States. Symptomatic trees were discovered and 'Ca. L. asiaticus' was confirmed infecting citrus in Florida in 2005 (Halbert 2005) and it is generally accepted that all commercial groves in Florida are now affected to some extent by HLB. The pathogen was confirmed infecting commercial citrus trees in

Corresponding author: M. E. Hilf; E-mail address: Mark.Hilf@ars.usda.gov

http://dx.doi.org/10.1094/PHYTO-09-15-0221-R

This article is in the public domain and not copyrightable. It may be freely reprinted with customary crediting of the source. The American Phytopathological Society, 2016
Texas in 2012 (Kunta et al. 2012) and in a single citrus tree in suburban southern California in 2012 (Kumagai et al. 2013); no infections of commercial citrus trees have been confirmed in California.

Citrus is considered the natural host for ' $\mathrm{Ca}$. L. asiaticus', although experimental transmission from citrus to periwinkle (Catharanthus roseus) (Garnier and Bové 1983) and tomato (Duan et al. 2008) using dodder (Cuscuta spp.) has been demonstrated, and dodder itself supports replication of ' $\mathrm{Ca}$. L. asiaticus' (Hartung et al. 2010b). The spread of ' $\mathrm{Ca}$. L. asiaticus' in commercial citrus is primarily via the ACP but also can occur by the vegetative propagation of infected citrus scion bud wood during the production of new trees (Bové 2006; Gottwald et al. 2007). Seed transmission has been considered a potential route of dissemination of the pathogen but published studies indicate that seed transmission is not an avenue of dissemination of the pathogen (Albrecht and Bowman 2009; Graham et al. 2011; Hartung et al. 2010a; Hilf 2011; Shatters 2008).

Despite decades of research, including many recent attempts (Davis et al. 2008; Parker et al. 2014; Sechler et al. 2009), a sustained, axenic laboratory culture of ' $\mathrm{Ca}$. L. asiaticus' has not been established. Therefore, research with ' $\mathrm{Ca}$. L. asiaticus' is conducted with ACP carrying bacteria acquired from infected citrus plants or, most commonly, research focuses on infected citrus plants. Under greenhouse conditions, the experimental transmission of ' $\mathrm{Ca}$. L. asiaticus' to noninfected plants can be accomplished using $\mathrm{ACP}$ raised on infected plants but because this requires the maintenance of not only plants but also insect colonies, the experimental infection of new plants is accomplished primarily by grafting.

Plants infected by graft transmission have been used to study a variety of aspects of the pathogen-citrus interaction, including changes in host gene expression due to infection (Albrecht and Bowman 2008, 2012; Aritua et al. 2013; Fan et al. 2011, 2012; Kim et al. 2009; Mafra et al. 2013; Nwugo et al. 2013; Zhao et al. 2013). For graft transmission, a stick of bud wood from an infected citrus plant typically is used as an inoculum source and budded to a receptor plant via an approach graft. Graft transmission of 
' $C a$. L. asiaticus' in this way is a reasonably effective method of transmitting and propagating the bacteria, with experimental transmission to sweet orange trees using bud sticks yielding 67 to $88 \%$ infected receptor trees over several experiments (Lopes et al. 2009a). In other instances ' $\mathrm{Ca}$. L. asiaticus' was transmitted using not bud sticks but a combination of smaller bark patches and leaf pieces grafted to the trunk of the receptor plant (Zhao et al. 2013).

For graft transmission and propagation of ' $\mathrm{Ca}$. L. asiaticus' by these standard practices, space is needed for the propagation of noninfected plants, for infected plants which act as inoculum sources, and for plants which are involved in ongoing experiments. Citrus plants used for this purpose are grown in a range of container sizes, some rather large (from 0.95 to 11.0 liters) (Hartung et al. 2010a; Lopes et al. 2009a), and a reasonable amount of greenhouse space is required to propagate and maintain these plants. A savings in space and materials and an increase in the number of concurrent experiments could be realized if ' $\mathrm{Ca}$. L. asiaticus' could be transmitted and propagated using smaller trees and smaller pieces of inoculum tissue.

The grafting of intact leaves to transmit viruses and phytoplasmas has been an effective method used in strawberry for some time (Frazier 1974; Greber and Gowanlock 1979; Martin et al. 2001). In citrus, viruses and viroids have been transmitted by grafting small leaf discs (Blue et al. 1976) but no information exists describing this or any method using whole or partial leaves solely as a method for the transmission and propagation of ' $\mathrm{Ca}$. L. asiaticus'.

We were interested in establishing a smaller-scale model system for graft transmission and propagation of ' $\mathrm{Ca}$. L. asiaticus'. In this work, we demonstrated that (i) citrus plants can be infected by grafting single leaves from infected trees with an effectiveness in transmission similar to that for bud sticks as reported in published works, (ii) plants inoculated in this manner develop symptoms indistinguishable from those displayed by plants grafted in the standard way, and (iii) very small seedlings can be inoculated by grafting single leaves and these small seedlings develop levels of bacteria and symptoms similar to those seen in much larger plants. We discussed several potential advantages of this method over the standard method of grafting larger bud sticks to obtain infection by ' $\mathrm{Ca}$. L. asiaticus' and how this method can be used to study important aspects of the ' $\mathrm{Ca}$. L. asiaticus'-citrus pathosystem.

\section{MATERIALS AND METHODS}

Propagation and maintenance of citrus seedlings. All trees used in this study were seedlings. Seeds of 'Ridge Pineapple' sweet orange (Citrus sinensis (L.)), sour orange (C. aurantium L.), and 'Cleopatra' mandarin (C. reticulata Blanco) were obtained from trees maintained on the United States Department of AgricultureAgricultural Research Service A. H. Whitmore Foundation Farm in Leesburg, FL. Seeds of C. macrophylla Wester and 'Carrizo' citrange (C. sinensis $\times$ Poncirus trifoliata (L.) Raf) were obtained from Willits and Newcomb, Inc., Arvin, CA. Seeds of 'Arizona 861$\mathrm{S}-1$ ' citron $(C$. medica $\mathrm{L}$.) were obtained from trees maintained in the greenhouse at the U.S. Horticultural Research Laboratory, Fort Pierce, FL. Seeds were germinated and seedlings were maintained in Ray Leach SC10U Cone-tainer cells (0.16 liters), (Stuewe \& Sons, Inc., Tangent, OR) using Pro Mix Mycorise soil mix (Premier Tech Horticulture, Rivièredu-Loup, Quebec, Canada). Some seedlings were transplanted to larger D40H Deepots (0.66 liters) (Stuewe \& Sons, Inc.) during the study. Seedlings were fertilized weekly with a general 20-10-20 liquid fertilizer mix and watered when needed. Temperatures in the greenhouse were moderated by evaporative cooling, with supplemental heating in winter when needed.

Ages of seedlings at the time of inoculation varied but, in general, were 3 to 9 months for sour orange, 18 months for 'Carrizo' citrange, 13 to 14 months for $C$. macrophylla, 16 months for 'Cleopatra' mandarin, 9 months for citron, and 10 to 15 months for 'Ridge Pineapple' sweet orange.

Grafting of whole leaves. Leaves for inoculation were chosen from trees designated as source trees for ' $\mathrm{Ca}$. L. asiaticus' inoculum and included leaves from symptomatic sour orange, sweet orange, and pummelo ( $C$. maxima (Burm.) Merrill). The presence of ' $C a$. L. asiaticus' had been confirmed by real-time polymerase chain reaction (qPCR) in all source trees prior to this study. Grafting of intact leaves was done by two methods. The primary method was designated the "decapitation" method because the receptor seedling was trimmed to a single stem and the petiole of the leaf was inserted into a small space made when the bark was pulled back from the wood (Fig. 1A). If needed, the petiolar end of the inoculum leaf was trimmed and shaped with a knife or scalpel to fit snugly under the bark. Parafilm was used to secure the bark snugly around the petiole. A small wooden stake was inserted into the soil adjacent to the plant stem and the tip of the grafted leaf was tied to the stake with a thin strip of Parafilm to keep the leaf upright while the tissues healed (Fig. 1A). This prevented the leaf from falling forward and possibly pulling itself out of place, which could prevent adequate contact between the tissues of the leaf and receptor plant. Newly grafted plants were kept in a cooler or air-conditioned greenhouse and the racks holding the containers were set in a shallow water-filled pan to maintain a higher level of humidity. In addition, grafted leaves were misted with water several times daily. Plants were maintained under these conditions until it was clear the grafted leaf was viable, usually by 3 weeks postgrafting. In addition to the decapitation method, leaves were grafted using a more standard side graft for a small set of seedlings. For this method, a small incision was made in the stem of the receptor seedling and the petiole of the inoculum leaf was inserted into the incision, which was sealed with Parafilm. The tip of the leaf was secured to the stem of the receptor tree with a thin strip of Parafilm, which kept the leaf in an upright position until the tissues healed. Plants grafted in this manner were held under the same environmental conditions until it was clear that the grafted leaf was viable.

Selection of leaves for detection of ' $\mathrm{Ca}$. L. asiaticus' in grafted plants. To detect ' $\mathrm{Ca}$. L. asiaticus' in new growth of seedlings inoculated by the decapitation method, if no leaves were clearly symptomatic, then leaves nearest the base of new adventitious shoots most proximal to the point of inoculation were selected for qPCR assay as described below, because it was postulated that these tissues would be colonized first by bacteria from the inoculum tissue. To detect ' $C a$. L. asiaticus' in seedlings inoculated by a side graft, mature leaves on the stem at various points above and below the point of inoculation were assayed, as well as leaves on new growth which emerged above and below the point of inoculation.

Nucleic acid extraction and assaying for bacterial DNA in plant tissue. Plant tissue $(0.18 \mathrm{~g})$ was pulverized in AP1 buffer (Qiagen, Valencia, CA) in a 2.0-ml microcentrifuge tube using a Mini-Beadbeater (Biospec Products Inc., Bartlesville, OK). The DNA was extracted from pulverized tissue with the DNeasey Plant Mini Kit (Qiagen). qPCR to detect the ' $\mathrm{Ca}$. L. asiaticus' 16S ribosomal RNA gene sequence was performed as described by Li et al. (2006) in $20 \mu \mathrm{l}$, with $25 \mathrm{ng}$ of DNA, $0.25 \mu \mathrm{M}$ each of the forward and reverse primers, $0.15 \mu \mathrm{M}$ probe, and $2 \times$ TaqMan Fast Universal PCR Master Mix (Applied Biosystems, Carlsbad, CA), with one cycle of denaturation at $95^{\circ} \mathrm{C}$ for $20 \mathrm{~s}$ followed by 40 cycles of denaturation for $3 \mathrm{~s}$ at $95^{\circ} \mathrm{C}$ and annealing or extension at $60^{\circ} \mathrm{C}$ for $30 \mathrm{~s}$ using an Applied Biosystems 7500 Fast Real-Time PCR System (Applied Biosystems). For each DNA sample, three equivalent volumes were analyzed. The number of ' $\mathrm{Ca}$. L. asiaticus' cells per sample was calculated using the following regression equation: $\log$ copy number $=(\mathrm{Ct}-36.3) /-3.16$, where $\mathrm{Ct}$ is the derived cycle threshold value. The final numbers of bacteria per sample were calculated, taking into consideration the sample volume and the sample tissue mass. 


\section{RESULTS}

Inoculum survival and infection. The grafting work described here was performed during January to July 2014. Figure 1 depicts the decapitation method described in Materials and Methods and shows a newly grafted leaf with vertical support to keep the leaf from falling forward and pulling itself out of the graft point (Fig. 1A) and the appearance of the petiole of the inoculum leaf recently inserted under the bark of the receptor plant and wrapped to retain moisture (Fig. 1B). As a contrast to the decapitation method, citron seedlings in this study were inoculated by inserting the petiole of the inoculum leaves as a side graft underneath a flap of bark on the trunk of the seedling (Fig. 1C and D).

In the main study, in total, 162 leaf-grafted seedlings were evaluated for infection and symptoms (Table 1). In all cases, 3 weeks was used as the standard time to determine that grafted tissue had healed successfully in place. For the purposes of this study, this 3week mark was the start of the incubation period for monitoring symptom development and infection of grafted seedlings. Grafted seedlings were evaluated periodically for foliar symptoms or effects on growth (stunting and chlorosis) indicative of infection with ' $C a$. L. asiaticus'. qPCR assays were performed on samplings of new growth, to confirm that infection of the receptor plant had occurred. The study was terminated on 30 June 2015 because this was considered sufficient time for infection to occur in all plants in the study.

The decapitation method of inoculation left no older tissue on the receptor seedlings; therefore, new, adventitious shoots were sampled to monitor the progress of infection in the inoculated seedling. Typically, with this method of grafting, new shoots emerged below the point of inoculation (Fig. 1E), with initial emergence often occurring during the 3-week evaluation period for establishment of the grafts. When the inoculum leaf was inserted as a side graft (Fig. 1C and D), existing tissues below the graft point and existing and new tissues above the graft point were sampled to evaluate movement of bacteria from the inoculum leaf.

In 119 of 162 cases $(73.5 \%)$ the grafted leaf was intact at the start of the incubation period but, in a smaller number of instances, only the petiole portion of the leaf remained (12 of $162,7.4 \%$ ) or there remained only a small amount of live inoculum tissue below the bark at the point of grafting (31 of 162, 19.1\%) on the recipient seedling (Table 1).

In total, 109 of 162 plants (67\%) were infected during this study based on the qPCR assay. For seedlings with the inoculum leaf intact at the start of the incubation period, 96 of $119(81 \%)$ were infected during the study period. In cases where the inoculum leaf did not survive intact until the start of the incubation period, 6 of 12 $(50 \%)$ and 7 of $24(23 \%)$ receptor plants were infected from intact petioles only or from tissue remnants under the bark, respectively (Table 1).

Seedlings of all five cultivars tested in this study were infected by leaf grafting, with the incidence of infection ranging from 23 of $46(50 \%)$ for sour orange to 24 of $25(96 \%)$ for Carrizo citrange. In contrast to the other cultivars, the citron seedlings were inoculated by whole leaves inserted as a side graft and the incidence of infection was 10 of $14(71 \%)$, an incidence similar to those for seedlings inoculated by the decapitation method.

Leaves used for inoculation were considered symptomatic if they exhibited an evident blotchy mottle or showed strong symptoms reminiscent of a nutrient deficiency such as zinc deficiency. Healthyappearing leaves and leaves exhibiting a diffuse, mild mottle were
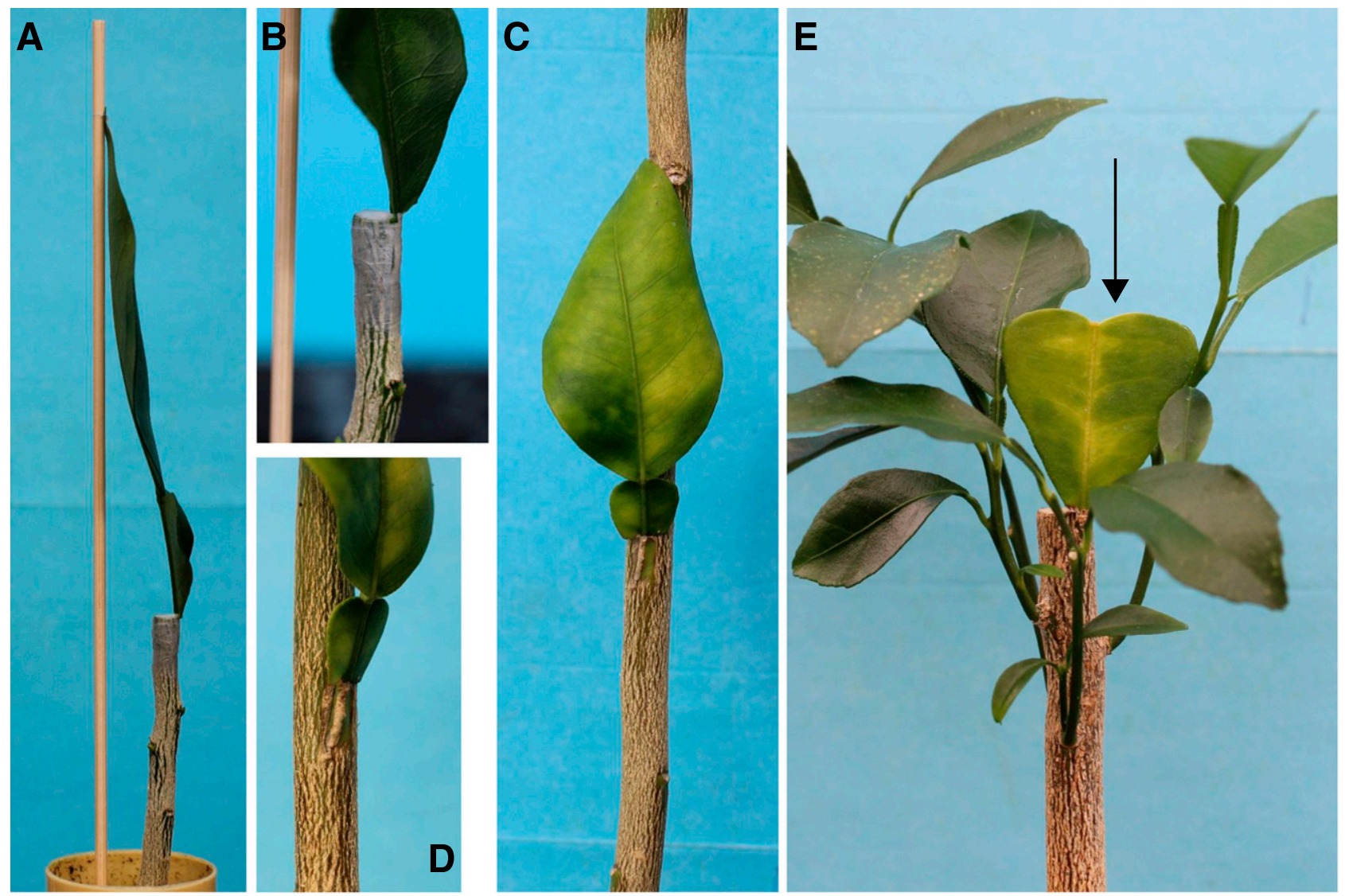

Fig. 1. Grafting of intact leaves to citrus plants. A, Side view of the decapitation method of grafting showing an intact leaf inserted into the receptor tree and tied to a stake for support. B, Close-up view of leaf in A to show insertion of the petiole of the inoculum leaf underneath the bark of the receptor tree and wrapping with Parafilm. C, Intact symptomatic leaf healed in place via an approach-type graft. D, Close-up of leaf in C, showing insertion of the base of the petiole underneath the bark of the receptor tree. $\mathbf{E}$, Arrow indicates the leaf petiole which remained alive and grafted in place after the leaf blade abscised. 
considered asymptomatic for HLB. For intact inoculum leaves among all cultivars, the incidence of infection was 35 of $41(85 \%)$ when symptomatic leaves were used as inoculum and 61 of $78(78 \%)$ when asymptomatic leaves were used (Table 1), indicating that infection can occur if leaves of either phenotype are used as a source of inoculum. The percentage of receptor plants infected with symptomatic leaves was significantly higher than for asymptomatic leaves $\left(\chi^{2}=4.57, P<0.05\right)$.

Symptoms developed in inoculated trees. Trees infected by leaf grafting displayed the range of symptoms seen on larger trees inoculated by the standard grafting method, and included the classic blotchy mottle foliar symptoms (Fig. 2A) and stunted chlorotic shoots, leaf epinasty, and vein corking (Fig. 2B). Response to infection could vary dramatically between seedlings of the same cultivar. At approximately 13 months postgrafting, a sour orange seedling showed extreme stunting and no new growth (Fig. 2C, right) whereas another seedling showed some leaves with characteristic blotchy mottle but otherwise exhibited relatively healthy-appearing growth at approximately 17 months postgrafting (Fig. 2C, left).

In addition to visual assessment of symptoms, infection was confirmed by detection of ' $\mathrm{Ca}$. L. asiaticus' DNA in tissues of inoculated trees. Typically, confirmation of infection by ' $\mathrm{Ca}$. L. asiaticus' in field samples is based on testing symptomatic tissues. Ten leaves showing the classic HLB-associated blotchy mottle foliar symptom (Fig. 2A) were selected from trees of each of the citrus types examined in this study. The ' $\mathrm{Ca}$. L. asiaticus'-specific qPCR was performed as described above; the ranges of $\mathrm{Ct}$ values generated and the calculated bacterial cells per gram of tissue are presented in Table 2. The sample Ct values and calculated cell numbers showed a range of variability similar to those in previous studies (Folimonova and Achor 2010; Li et al. 2009). The purpose of presenting these data is solely to demonstrate that the classic foliar HLB symptoms seen in plants inoculated by grafted leaves are associated with infection by ' $\mathrm{Ca}$. L. asiaticus'.

Inoculation and symptom development on small seedlings. A subset of seedlings used in this experiment were 3 to 6 months old when inoculated. These seedlings were chosen (i) to demonstrate that these small seedlings could be infected by the leaf-grafting method, because they were too small to infect with by the standard method of graft transmission using larger pieces of bud wood, and (ii) to observe growth and symptom development in these small seedlings. Inoculating young, small seedlings with ' $\mathrm{Ca}$. L. asiaticus' was envisioned as a means of creating a small-scale model whereby the entire infected seedling (roots and shoots) could be harvested and analyzed for various physiological and genetic changes. The apex was removed, resulting in seedlings which had heights of approximately 4.0 to $7.5 \mathrm{~cm}$, and small symptomatic leaves were grafted to the seedlings.

In some instances, these young seedlings displayed the deleterious effect of ' $\mathrm{Ca}$. L. asiaticus' infection in the first tissues to emerge postinoculation whereas, in others, the inoculum leaf healed in place but no adventitious growth emerged from the inoculated seeding (data not shown). In most cases, adventitious shoots emerged postinoculation and grew to a limited extent. Typical of the latter group was a grapefruit seedling inoculated at 3 months with a small, symptomatic leaf (Fig. 2D, horizontal arrow). At 6 months postinoculation (Fig. 2D), symptoms of infection were evident and analysis of a sample of symptomatic tissue showed a bacterial titer of $5.31 \times 10^{6}$ cells g $^{-1}$ tissue $(\mathrm{Ct}=21.1)$. At approximately 10 months postinoculation, symptoms had progressed in severity, with pronounced leaf epinasty, chlorosis, and thickening of the mid- and lateral veins in the leaves (Fig. 2E). These data indicate that small seedlings inoculated by leaf grafting can exhibit a progression of symptoms and support growth of bacteria to an extent similar to that observed in larger plants.

\section{DISCUSSION}

Vegetative grafting is an accepted practice for propagation of many systemic plant pathogens, including ' $\mathrm{Ca}$. L. asiaticus', the bacterium associated with the citrus disease HLB. For propagation of ' $\mathrm{Ca}$. L. asiaticus', a larger plant typically is used as a receptor plant because a tree of this size can accommodate an inoculum bud stick of the size commonly used for vegetative propagation (Lopes et al. 2009a). Once a vascular connection is established between the bud stick and the receptor tree, bacteria can move from the inoculum and colonize the tissues of the receptor plant.

The work described here demonstrates that single, intact leaves from an infected citrus plant can be a sufficient source of inoculum to initiate a new infection in trees of varying sizes and ages, with the subsequent development of HLB. Grafting leaves or portions of leaves to transmit a pathogen has been demonstrated for citrus viruses (Blue et al. 1976) and for viruses and phytoplasmas in strawberry (Frazier 1974; Greber and Gowanlock 1979) but, to our knowledge, this is the first reported demonstration of transmission of a systemic bacterial citrus pathogen using single leaves as the source of inoculum. Infection occurred with similar success if symptomatic or asymptomatic leaves from infected trees were used, with incidences of 85 and $78 \%$, respectively. In all cases, an intact leaf was the initial inoculum but, in 43 cases (approximately 27\%),

TABLE 1. Incidence of infection in citrus seedlings grafted with citrus leaves from source trees infected with 'Candidatus Liberibacter asiaticus'

\begin{tabular}{|c|c|c|c|c|c|c|}
\hline \multirow[b]{2}{*}{ Citrus type } & \multirow[b]{2}{*}{ Infection $^{\mathrm{b}}$} & \multicolumn{4}{|c|}{ Inoculum type } & \multirow[b]{2}{*}{ Totals $(\%)^{\mathrm{d}}$} \\
\hline & & Symp & Asym & Petiole & Tissue $^{c}$ & \\
\hline \multirow[t]{2}{*}{ Citrus macrophylla } & + & 1 & 13 & 1 & 0 & $15(83)$ \\
\hline & - & 0 & 3 & 0 & 0 & 3 (17) \\
\hline \multirow[t]{2}{*}{ Citrange 'Carrizo' } & + & 12 & 11 & 0 & 1 & $24(96)$ \\
\hline & - & 0 & 1 & 0 & 0 & $1(4)$ \\
\hline \multirow[t]{2}{*}{ Sour orange } & + & 4 & 12 & 2 & 5 & $23(50)$ \\
\hline & - & 4 & 8 & 3 & 8 & $23(50)$ \\
\hline \multirow[t]{2}{*}{ Citron } & + & 10 & 0 & 0 & 0 & $10(71)$ \\
\hline & - & 2 & 1 & 1 & 0 & 4 (29) \\
\hline \multirow[t]{2}{*}{ Mandarin 'Cleopatra' } & + & 1 & 9 & 2 & 0 & $12(57)$ \\
\hline & - & 0 & 2 & 0 & 7 & $9(43)$ \\
\hline \multirow[t]{2}{*}{ Sweet orange 'Ridge Pineapple' } & + & 7 & 16 & 1 & 1 & $25(66)$ \\
\hline & - & 0 & 2 & 2 & 9 & $13(34)$ \\
\hline \multirow[t]{2}{*}{ All types } & + & $35(85)$ & $61(78)$ & $6(50)$ & $7(23)$ & $109(67)$ \\
\hline & - & $6(15)$ & $17(22)$ & $6(50)$ & $24(77)$ & $53(33)$ \\
\hline
\end{tabular}

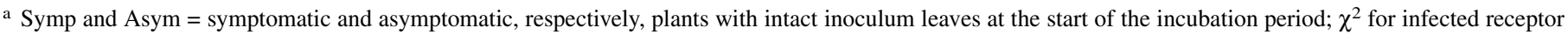
trees was $4.57(P<0.05)$. Petiole = petiole only.

b Infection status as determined by real-time polymerase chain reaction; + indicates infected and - indicates not infected.

c Tissue remnant. Live inoculum tissue was observed under the bark at the graft site but no tissue was external at the graft point.

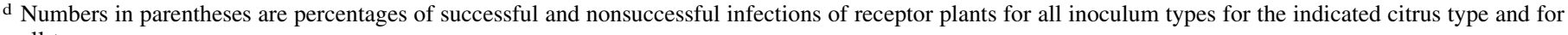
all types. 
plants began the incubation period with either only an intact petiole remaining (the remainder of the leaf blade not having survived the grafting stage) or with only a small remnant of inoculum tissue having survived the grafting process under the bark of the receptor tree. The low but unexpected incidence of infection from only a tissue remnant $(23 \%)$ indicates that a smaller population of bacteria than is normally present in a larger inoculum can initiate infection in the receptor seedling. It is possible that this is the case in all instances of successful grafting to transmit ' $\mathrm{Ca}$. L. asiaticus', because no research has identified which cells in the inoculum bud wood are the source of bacteria that initially migrate from the inoculum into the receptor host. The bacteria which initially colonize the receptor plant may, in fact, reside in a small number of cells in the inoculum tissue closest to the point of grafting. The much higher incidence of infection obtained with intact leaves, however, suggests that a larger population of inoculating bacteria more likely will result in the infection of the receptor plant.

In this study, approximately $19 \%$ of trees with intact leaves at the start of the incubation period were not infected by the termination of the study, and the rate of failure was similar when either symptomatic $(15 \%)$ or asymptomatic leaves $(22 \%)$ were used as inoculum. The reason for these failures is not known but it is reasonable to assume that the titer of bacteria in these leaves as well as the physiological state of the bacteria will have influenced the outcome. An assessment of the bacterial levels in these leaves was not done; therefore, it is possible that no bacteria were present in these asymptomatic leaves. This is less likely for the symptomatic leaves, because these foliar symptoms are consistently associated with the presence of ' $\mathrm{Ca}$. L. asiaticus' (Bové 2006; Gottwald et al. 2007). Published studies which measured bacterial cell viability in symptomatic citrus tissues found that the viable portion of the population could be as low as $17 \%(\mathrm{Hu}$ et al. 2013; Trivedi et al. 2009); therefore, it is possible that the viable population of cells in these leaves was below a threshold level needed to initiate an infection.

One consistent characteristic of the plants inoculated by the decapitation method was the near simultaneous emergence of new adventitious shoots on these plants. The developmental equivalency of these multiple shoots should facilitate studies on timing of infection, rates of colonization, and bacterial population development in newly colonized tissues and the progression and timing of

TABLE 2. Real-time polymerase chain reaction (qPCR) cycle threshold (Ct) data and calculated bacterial cell populations determined from samples of huanglongbing-symptomatic leaves

\begin{tabular}{|c|c|c|c|c|}
\hline \multirow[b]{2}{*}{ Citrus type } & \multicolumn{2}{|c|}{ qPCR Ct values } & \multicolumn{2}{|c|}{ Populations (cells/g) } \\
\hline & Range & Mean & Range & Mean \\
\hline $\begin{array}{l}\text { Citrus } \\
\quad \text { macrophylla }\end{array}$ & $22.5-27.3$ & 25.9 & $5.80 \times 10^{4}-1.92 \times 10^{6}$ & $1.60 \times 10^{5}$ \\
\hline Citrange & & & & \\
\hline 'Carrizo' & $21.1-25.1$ & 22.7 & $2.87 \times 10^{5}-5.30 \times 10^{6}$ & $1.65 \times 10^{6}$ \\
\hline Sour orange & $22.0-28.1$ & 25.3 & $3.23 \times 10^{4}-2.75 \times 10^{6}$ & $2.49 \times 10^{5}$ \\
\hline Citron & $22.9-28.2$ & 24.9 & $3.00 \times 10^{4}-1.43 \times 10^{6}$ & $3.33 \times 10^{5}$ \\
\hline $\begin{array}{l}\text { Mandarin } \\
\text { 'Cleopatra' }\end{array}$ & $20.7-30.8$ & 25.9 & $4.52 \times 10^{3}-7.09 \times 10^{6}$ & $1.61 \times 10^{5}$ \\
\hline $\begin{array}{l}\text { Sweet orange } \\
\text { 'Ridge }\end{array}$ & & & & \\
\hline Pineapple' & $20.1-26.8$ & 23.0 & $8.33 \times 10^{4}-1.10 \times 10^{7}$ & $1.33 \times 10^{6}$ \\
\hline
\end{tabular}

a 'Candidatus Liberibacter asiaticus' populations.
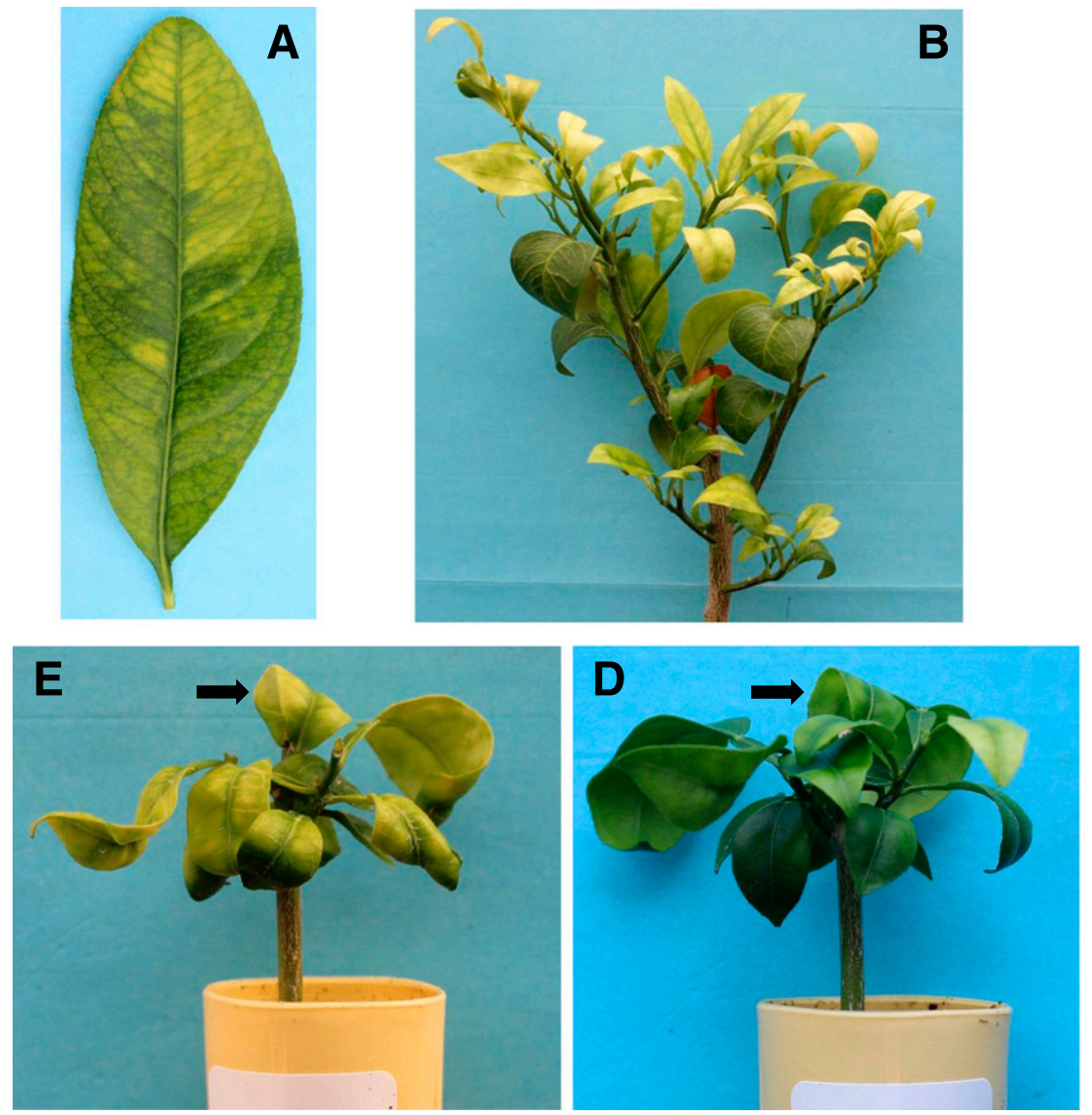

B
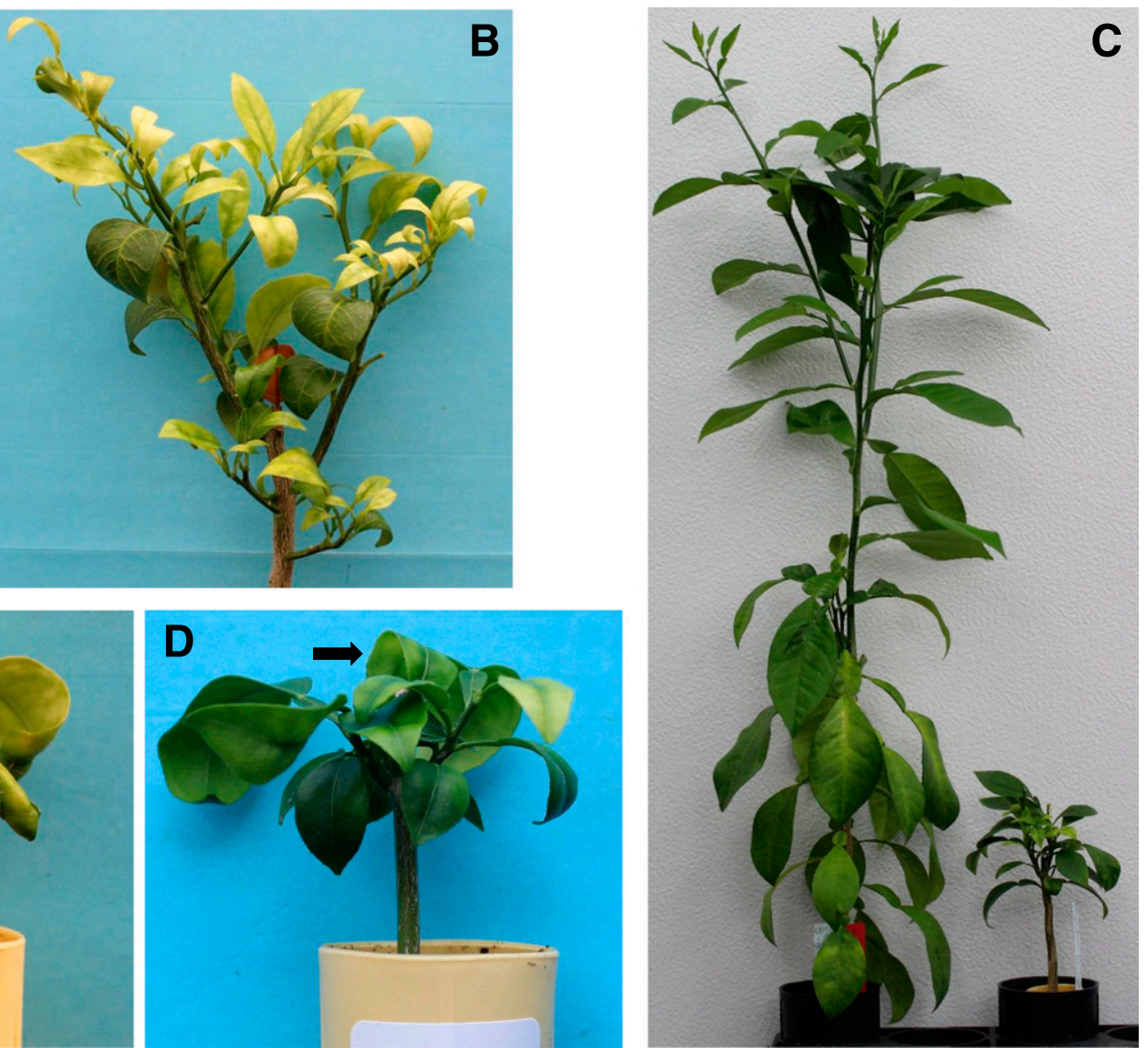

Fig. 2. Huanglongbing (HLB) symptoms expressed by plants inoculated via leaf grafts. A, Leaf of a Citrus medica plant showing the distinctive blotchy mottle considered characteristic for HLB. B, Sweet orange seedling showing severely stunted and chlorotic flush, leaf epinasty, and vein corking; the dead petiole of the grafted leaf can be seen in the center of the figure still attached to the receptor tree. $\mathbf{C}$, Two sour orange seedlings showing the variable responses to infection obtained via leaf grafting. Symptoms expressed at D, 6 months and $\mathbf{E}, 10$ months postinoculation by the limited growth which emerged from this small grapefruit seedling; in both panels, the arrow indicates the grafted inoculum leaf. 
symptom expression in these new tissues. Research assessing changes in host gene expression have provided insight into the molecular interactions between ' $\mathrm{Ca}$. L. asiaticus' and the citrus host (Albrecht and Bowman 2008, 2012; Fan et al. 2011, 2012; Mafra et al. 2013; Nwugo et al. 2013; Zhao et al. 2013). In these studies, analyses of transcriptional changes due to infection were done on samples of tissue from a larger plant. As demonstrated in this study, very small seedlings can be infected by the leaf grafting method and develop symptoms similar to those seen in larger plants. These small seedlings could provide an alternative model for studying changes in gene expression because these small seedlings would allow researchers to assess transcriptional changes in all tissues of a single plant, with multiple seedlings being analyzed in a single study.

Recent studies examined the effect of antibiotics on ' $\mathrm{Ca}$. L. asiaticus' populations in citrus tissues by application of compounds as root drenches (Zhang et al. 2011) or by soaking bud sticks in solutions of antibiotics followed by grafting the bud sticks to receptor plants (Zhang et al. 2014). The leaf-grafting method provides an alternative method of testing, whereby these compounds can be applied directly to an intact leaf and the effectiveness of a treatment can be measured as a direct effect on the incidence of transmission of ' $\mathrm{Ca}$. L. asiaticus' from this leaf to the receptor tree. In another study, different formulations of emulsifying compounds were tested as aids to the penetration of antibiotics into citrus leaf tissues by application to isolated leaf cuticles (Yang et al. 2015). The leaf grafting method would simplify this process of evaluation by circumventing the need to isolate cuticles because these solutions could be applied directly to the inoculum leaf, and their ability to facilitate penetration of antibiotics could be evaluated more directly as an effect on the transmission of ' $\mathrm{Ca}$. L. asiaticus'.

When a bud stick is grafted as an inoculum source for transmission of ' $\mathrm{Ca}$. L. asiaticus', the grafted inoculum may or may not develop adventitious shoots; however, if new growth occurs, this new growth potentially can act as an additional and continual source of bacteria for colonization of the receptor plant.

In contrast, insect transmission of ' $C a$. L. asiaticus' by the ACP occurs when adult psyllids inject bacteria directly into plant phloem cells during feeding. Experimentally, adults are allowed to feed for a defined period to allow inoculation and, once the bacteria are established and replicating in these cells, eventual systemic infection of the tree results when bacteria move via the phloem from this initial site of inoculation to colonize additional parts of the plant. No additional inoculation by ACP is required for a successful infection (Ammar et al. 2011, 2013).

Leaves are terminally differentiated tissues; therefore, no additional growth of the leaf occurs when grafted to a receptor plant. However, as long as some grafted leaf tissue remains alive and attached to the receptor plant, the tissue remains a potential source for more bacteria which can move into the receptor plant; it is not known if the population of ' $\mathrm{Ca}$. L. asiaticus' increases in the inoculum leaf once it successfully grafts. During the course of this study, it was noted that many grafted leaves eventually would senesce and die, dropping from the receptor plant and leaving no visible residual leaf material below the point of attachment (data not presented). By this time, the infection was well established in the receptor plant and the progress of the infection and disease development seemingly was not affected by the loss of the inoculum source. In comparison, the biology of inoculation by grafted leaves appears intermediate between that of the standard grafting procedure and ACP transmission, mimicking the former if the leaf survives for an extended time after grafting and mimicking the latter if the inoculum leaf is lost shortly after grafting and transmission of ' $\mathrm{Ca}$. L. asiaticus' to the receptor plant has already occurred. The minimal amount of time needed for ' $\mathrm{Ca}$. L. asiaticus' cells to move from a grafted inoculum source to the receptor plant has not been established but the leaf-grafting method is a suitable method to determine this.

This study demonstrated that single leaves from ' $\mathrm{Ca}$. L. asiaticus'infected citrus trees can be successfully grafted to citrus trees of varying ages and sizes with a high incidence of subsequent infection of the receptor plant and the development of symptoms typical of HLB. Very small seedlings were infected in this manner, with subsequent infection and expression of symptoms similar to that of much larger plants, indicating that these smaller plants can serve as a reductionist model for studies on host-pathogen interactions. This leaf-grafting procedure is a novel and effective additional tool and its application should provide increased experimental flexibility for studying the various aspects of this complicated pathosystem.

\section{ACKNOWLEDGMENTS}

We thank K. Sims, K. Smolarek, and A. Champion for excellent technical assistance on this project. Mention of a trade name, proprietary product, or specific equipment does not constitute a guarantee of warranty by the U.S. Department of Agriculture and does not imply approval to the exclusion of other products that may also be suitable.

\section{LITERATURE CITED}

Albrecht, U., and Bowman, K. D. 2008. Gene expression in Citrus sinensis (L.) Osbeck following infection with the bacterial pathogen 'Candidatus Liberibacter asiaticus' causing huanglongbing in Florida. Plant Sci. 175:291306

Albrecht, U., and Bowman, K. D. 2009. 'Candidatus Liberibacter asiaticus' and huanglongbing effects on citrus seeds and seedlings. Hortic. Sci. 44: 1967-1973.

Albrecht, U., and Bowman, K. D. 2012. Transcriptional response of susceptible and tolerant citrus to infection with 'Candidatus Liberibacter asiaticus'. Plant Sci. 185-186:118-130.

Ammar, E.-D., Shatters, R. G., Jr., Lynch, C., and Hall, D. G. 2011. Detection and relative titer of 'Candidatus Liberibacter asiaticus' in the salivary glands and alimentary canal of Diaphorina citri (Hemiptera: Psyllidae) vector of citrus huanglongbing disease. Ann. Entomol. Soc. Am. 104:526533.

Ammar, E.-D., Walter, A. J., and Hall, D. G. 2013. New excised-leaf assay method to test inoculativity of Asian citrus psyllid (Hemiptera: Psyllidae) with 'Candidatus Liberibacter asiaticus' associated with citrus huanglongbing. J. Econ. Entomol. 106:25-35.

Aritua, V., Achor, D., Gmitter, F. G., Albrigo, G., and Wang, N. 2013. Transcriptional and microscopic analyses of citrus stem and root responses to 'Candidatus Liberibacter asiaticus' infection. PLoS One 8:e73742.

Blue, R. L., Roistacher, C. N., Cartia, G., and Calavan, E. C. 1976. Leaf-disc grafting-a rapid indexing method for detection of some citrus viruses. Pages 207-212 in: Proc. 7th Conf. Int. Organ. Citrus Virol. IOCV, Riverside, CA.

Bové, J. M. 2006. Huanglongbing: A destructive, newly-emerging, century-old disease of citrus. J. Plant Pathol. 88:7-37.

Coletta-Filho, H. D., Targon, M. L. P. N., Takita, M. A., De Negri, J. D., Pompeu, J., Jr., and Machado, M. A. 2004. First report of the causal agent of huanglongbing 'Candidatus Liberibacter asiaticus' in Brazil. Plant Dis. 88: 1382 .

Davis, M. J., Mondal, S. N., Chen, H., Rogers, M. E., and Brlansky, R. H. 2008. Co-cultivation of 'Candidatus Liberibacter asiaticus' with actinobacteria from citrus with huanglongbing. Plant Dis. 92:1547-1550.

Duan, Y. P., Gottwald, T., Zhou, L. J., and Gabriel, D. W. 2008. First report of dodder transmission of 'Candidatus Liberibacter asiaticus' to tomato (Lycopersicum esculentum). Plant Dis. 92:831.

Fan, J., Chen, C., Yu, Q., Brlansky, R. H., Li, Z., and Gmitter, F. G. 2011. Comparative iTRAQ proteome and transcriptome analyses of sweet orange infected by 'Candidatus Liberibacter asiaticus'. Physiol. Plant. 143:235-245.

Fan, J., Chen, C., Yu, Q., Khalaf, A., Achor, D. S., Brlansky, R. H., Moore, G. A., Li, Z.-G., and Gmitter, F. G. 2012. Comparative transcriptional and anatomical analyses of tolerant rough lemon and susceptible sweet orange in response to 'Candidatus Liberibacter asiaticus' infection. Mol. PlantMicrobe Interact. 25:1396-1407.

Folimonova, S. Y., and Achor, D. S. 2010. Early events of citrus greening (huanglongbing) disease development at the ultrastructural level. Phytopathology 100:949-958.

Frazier, N. W. 1974. Detection of graft-transmissible diseases in strawberry by a modified leaf grafting technique. Plant Dis. Rep. 58:203-208.

French, J. V., Kahlke, C. J., and da Graca, J. V. 2001. First record of the Asian citrus psylla, Diaphorina citri Kuwayama (Homoptera: Psyllidae), in Texas. Subtrop. Plant Sci. 53:14-15.

Garnier, M., and Bové, J. M. 1983. Transmission of the organism associated with citrus greening disease from sweet orange to periwinkle by dodder. Phytopathology 73:1358-1363. 
Gottwald, T. R., da Graça, J. V., and Bassanezi, R. B. 2007. Citrus huanglongbing: The pathogen and its impact. Online publication. Plant Health Prog. doi:10.1094/PHP-2007-0906-01-RV

Graham, J., Johnson, E. G., Bright, D. B., and Irey, M. S. 2011. Lack of development of huanglongbing in seedlings from citrus seed. Proc. Fla. State Hortic. Soc. 124:65-68.

Greber, R. S., and Gowanlock, D. H. 1979. Rickettisa-like and mycoplasmalike organisms associated with two yellows-type diseases of strawberries in Queensland. Aust. J. Agric. Res. 30:1101-1109.

Halbert, S. E. 1998. Entomology section. Tri-ology 37:6-7.

Halbert, S. E. 2005. The discovery of huanglongbing in Florida. Page 50 in: Proc. 2nd Int. Workshop Citrus Canker Huanglongbing, Orlando, FL.

Hartung, J. S., Halbert, S. E., Pelz-Stelinksi, K., Brlansky, R. H., Chen, C., and Gmitter, F. G. 2010a. Lack of evidence for transmission of 'Candidatus Liberibacter asiaticus' through citrus seed taken from affected fruit. Plant Dis. 94:1200-1205.

Hartung, J. S., Paul, C., Achor, D., and Brlansky, R. H. 2010b. Colonization of dodder, Cuscuta indecora, by 'Candidatus Liberibacter asiaticus' and 'Ca. L. americanus'. Phytopathology 100:756-762.

Hilf, M. E. 2011. Colonization of citrus seed coats by 'Candidatus Liberibacter asiaticus': Implications for seed transmission of the bacterium. Phytopathology 101:1242-1250.

Hu, H., Davis, M. J., and Brlansky, R. H. 2013. Quantification of live 'Candidatus Liberibacter asiaticus' populations using real-time PCR and propidium monoazide. Plant Dis. 97:1158-1167.

Kim, J.-S., Sagaram, U. S., Burns, J. K., Li, J.-L., and Wang, N. 2009. Response of sweet orange (Citrus sinensis) to 'Candidatus Liberibacter asiaticus' infection: Microscopy and microarray analyses. Phytopathology 99:50-57.

Kumagai, L. B., LeVesque, C. S., Blomquist, C. L., Madishetty, K., Guo, Y., Woods, P. W., Rooney-Latham, S., Rascoe, J., Gallindo, T., Schnabel, D., and Polek, M. 2013. First report of 'Candidatus Liberibacter asiaticus' associated with citrus huanglongbing in California. Plant Dis. 97:283.

Kunta, M., Sétamou, M., Skaria, M., Rascoe, J. E., Li, W., Nakhla, M. K., and da Graça, J. V. 2012. First report of citrus huanglongbing in Texas. (Abstr.) Phytopathology 102:S4.66.

Li, W., Hartung, J., and Levy, L. 2006. Quantitative real-time PCR for detection and identification of 'Candidatus Liberibacter asiaticus' associated with citrus huanglongbing. J. Microbiol. Methods 66:104-115.

Li, W., Levy, L., and Hartung, J. S. 2009. Quantitative distribution of 'Candidatus Liberibacter asiaticus' in citrus plants with citrus huanglongbing. Phytopathology 99:139-144.

Lopes, S. A., Bertolini, E., Frare, G. F., Martins, E. C., Wulff, N. A., Teixeira, D. C., Fernandes, N. G., and Cambra, M. 2009a. Graft transmission efficiencies and multiplication of 'Candidatus Liberibacter americanus' and ' $C a$. Liberibacter asiaticus' in citrus plants. Phytopathology 99:301-306.

Lopes, S. A., Frare, G. F., Bertolini, E., Cambra, M., Fernandes, N. G., Ayres, A. J., Marin, D. R., and Bové, J. M. 2009b. Liberibacters associated with citrus huanglongbing in Brazil: 'Candidatus Liberibacter asiaticus' is heat tolerant, ' $C a$. L. americanus' is heat sensitive. Plant Dis. 93:257-262.

Mafra, V., Martins, P. K., Francisco, C. S., Ribeiro-Alves, M., Freitas-Astúa, J., and Machado, M. A. 2013. 'Candidatus Liberibacter americanus' induces significant reprogramming of the transcriptome of the susceptible citrus genotype. BMC Genomics 14:247.

Martin, R. R., Hokanson, S. C., Maas, J. L., Heflebower, R. F., and Rouse, R. 2001. Survey of strawberry viruses occurring in commercial plantings in the state of Maryland, USA. Acta Hortic. 551:71-74.

Nwugo, C. C., Duan, Y., and Lin, H. 2013. Study on citrus response to huanglongbing highlights a down-regulation of defense-related proteins in lemon plants upon ' $\mathrm{Ca}$. Liberibacter asiaticus' infection. PLoS One 8: e67442.

Parker, J. K., Wisotsky, S. R., Johnson, E. G., Hijaz, F. M., Killiny, N., Hilf, M. E., and De La Fuente, L. 2014. Viability of 'Candidatus Liberibacter asiaticus' prolonged by addition of citrus juice to culture medium. Phytopathology 104:15-26.

Pietersen, G., Arrebola, E., Breytenbach, J. H. J., Korsten, L., le Roux, H. F., la Grange, H., Lopes, S. A., Meyer, J. B., Pretorius, M. C., Schwerdtfeger, M., van Vuuren, S. P., and Yamamoto, P. 2010. A survey for 'Candidatus Liberibacter' species in South Africa confirms the presence of only ' $\mathrm{Ca}$. L. africanus' in commercial citrus. Plant Dis. 94:244-249.

Sechler, A., Schuenzel, E. L., Cooke, P., Donnua, S., Thaveechai, N., Postnikova, E., Stone, A. L., Schneider, W. L., Damsteegt, W. L., and Schaad, N. W. 2009. Cultivation of 'Candidatus Liberibacter asiaticus', 'Ca. L. africanus' and 'Ca. L. americanus' associated with huanglongbing. Phytopathology 99:480-486.

Shatters, R. G., Jr. 2008. Detection of 'Candidatus Liberibacter asiaticus' in citrus seedlings germinated from Florida seed. Page 198 in: Proc. Int. Res. Conf. Huanglongbing. T. R. Gottwald and J. H. Graham, eds. http://www. plantmanagementnetwork.org/proceedings/irchlb/2008/

Teixeira, D. C., Saillard, C., Eveillard, S., Danet, J. L., da Costa, I., Ayres, A. J., and Bové, J. 2005. 'Candidatus Liberibacter americanus' associated with citrus huanglongbing (greening disease) in São Paulo State, Brazil. Int. J. Syst. Bacteriol. 55:1857-1862.

Trivedi, P., Sagaram, U. S., Kim, J.-S., Brlansky, R. H., Rogers, M. E., Stelinksi, L. L., Oswalt, C., and Wang, N. 2009. Quantification of viable 'Candidatus Liberibacter asiaticus' in hosts using quantitative PCR with the aid of ethidium monoazide. Eur. J. Plant Pathol. 124:553-563.

Yang, C., Powell, C. A., Duan, Y., Shatters, R., and Zhang, M. 2015. Antimicrobial nanoemulsion formulation with improved penetration of foliar spray through citrus leaf cuticles to control citrus huanglongbing. PLoS One 10:e0133826.

Zhang, M., Guo, Y., Powell, C. A., Doud, M. S., Yang, C., and Duan, Y. P. 2014. Effective antibiotics against 'Candidatus Liberibacter asiaticus' in HLB-affected citrus plants identified via the graft-based evaluation. PLoS One 9:e111032.

Zhang, M., Powell, C. A., Zhou, L. J., He, Z., Stover, E., and Duan, Y. P. 2011. Chemical compounds effective against citrus huanglongbing bacterium 'Candidatus Liberibacter asiaticus' in planta. Phytopathology 101:1097-1103.

Zhao, H., Sun, R., Albrecht, U., Padmanabhan, C., Wang, A., Coffey, M. D., Girke, T., Wang, Z., Close, T. J., Roose, M., Yokomi, R. K., Folimonova, S., Vidalakis, G., Rouse, R., Bowman, K. D., and Jin, H. 2013. Small RNA profiling reveals phosphorus deficiency as a contributing factor in symptom expression for citrus huanglongbing disease. Mol. Plant 6:301-10. 